\title{
Autumn migration of Ospreys from two distinct populations in Poland reveals partial migratory divide
}

\author{
Dariusz Anderwald ${ }^{1,2}$, Łukasz Czajka², Sławomir Rubacha ${ }^{2}$, Michał Zygmunt ${ }^{2}$ and Paweł Mirski ${ }^{2,3^{*}}$ (1)
}

\begin{abstract}
Background: Long-term ringing and telemetry studies show that the Osprey (Pandion haliaetus) is a broad-front migrant following different migratory flyways, depending on the geographical location of their breeding populations. We have investigated two distinct and declining populations of Osprey in Poland, separated by only a few hundred kilometres, and hypothesised they may exhibit two different migration routes. We followed mortality causes, comparing them between migration and stationary phases of annual cycle, as well as between two distinct populations.
\end{abstract}

Methods: Nineteen Ospreys, both juveniles and adults, were equipped with GPS loggers in 2017-2020 in two populations in western and eastern Poland and followed on their autumn migration. We calculated the distance they covered on the migration, number of stopover days, migration duration, daily distances covered and departure dates to compare them between age and sex classes and between the eastern and western populations.

Results: Ospreys from the western and eastern populations showed a partial migratory divide. While the first migrated through a western flyway, the second followed a central flyway, resulting in crossing the Mediterranean Sea in distant passes that affected the distance covered. Annual mortality reached at least $67 \%$ in juveniles and at least $57 \%$ in adults.

Conclusions: We showed that two distinct Osprey populations in Poland revealed a partial migratory divide, with one covering greater distances over sea and deserts over the central flyway. This might affect individual survival rates and contribute to a steeper decline in one of the populations. In order for this to be confirmed, more individuals still have to be followed.

Keywords: GPS telemetry, Mortality, Pandion haliaetus, Stopover

\section{Background}

Revealing bird migration patterns is crucial to understanding the factors limiting populations of long-distance migratory species. Migrations are considered the most dangerous part of the annual cycle and mortality at that time may exceed that of the breeding and wintering periods even six-fold (Klaassen et al. 2014). The

*Correspondence: p.mirski@uwb.edu.pl

2 Eagle Conservation Committee, Niepodległości 53/55, 10-044 Olsztyn, Poland

Full list of author information is available at the end of the article differentiation of migration routes between populations is known to affect individuals' survival and, effectually, also whole population trends (Hewson et al. 2016). Therefore, it is justified to investigate migratory behaviour of selected, especially declining, populations of species, although they already seem sufficiently studied. One such extensively studied species is the Osprey (Pandion haliaetus; see Bierregaard et al. 2014 for summary of migration studies). It is a true cosmopolitan species, considered a long-distance migrant in most of the Northern Hemisphere (Martell et al. 2011; MacKrill 2017), but also a sedentary or partial-migratory species in lower original author(s) and the source, provide a link to the Creative Commons licence, and indicate if changes were made. The images or other third party material in this article are included in the article's Creative Commons licence, unless indicated otherwise in a credit line to the material. If material is not included in the article's Creative Commons licence and your intended use is not permitted by statutory regulation or exceeds the permitted use, you will need to obtain permission directly from the copyright holder. To view a copy of this licence, visit http://creativecommons.org/licenses/by/4.0/. The Creative Commons Public Domain Dedication waiver (http://creativeco mmons.org/publicdomain/zero/1.0/) applies to the data made available in this article, unless otherwise stated in a credit line to the data. 
latitudes (Monti et al. 2018a). A great body of studies have shown that Ospreys can migrate in broad-front. A study by Østnes et al. (2019) can serve as a good example of such a flexible migration pattern, where juveniles dispersed in different directions and crossed the Mediterranean Sea at known bottlenecks but also through open sea. On the other hand, depending on the geographical location of populations, Ospreys tend to show some general "highways" and minor paths (Fig. 1). Individuals from western Europe (United Kingdom, Germany, Norway and Sweden) were shown to most frequently use (but not exclusively) the western-most Mediterranean passage through the Iberian Peninsula (Alerstam et al. 2006; Klaassen et al. 2011; Mackrill 2017; Meyburg et al. 2018).
This seems logical and, consequently, the Ospreys from eastern Europe (Russia, Baltic countries and some from Finland) passed the Mediterranean Sea along its eastern shore or the Balkan Peninsula (Väli and Sellis 2015; Babushkin et al. 2019; LUOMUS 2020). The central Mediterranean passage through Corsica and Italian Peninsula were used by the Ospreys from central (e.g. Germany) and both, eastern and western Europe, but to a lesser degree. Finally, crossing the sea at its full width without any insurance of peninsulas and islands is also a common phenomenon in the case of this species. However, taking into account that migratory behaviour of soaring raptors, such as the Osprey, is most likely governed by innate mechanism (Väli et al. 2018), resembling the one

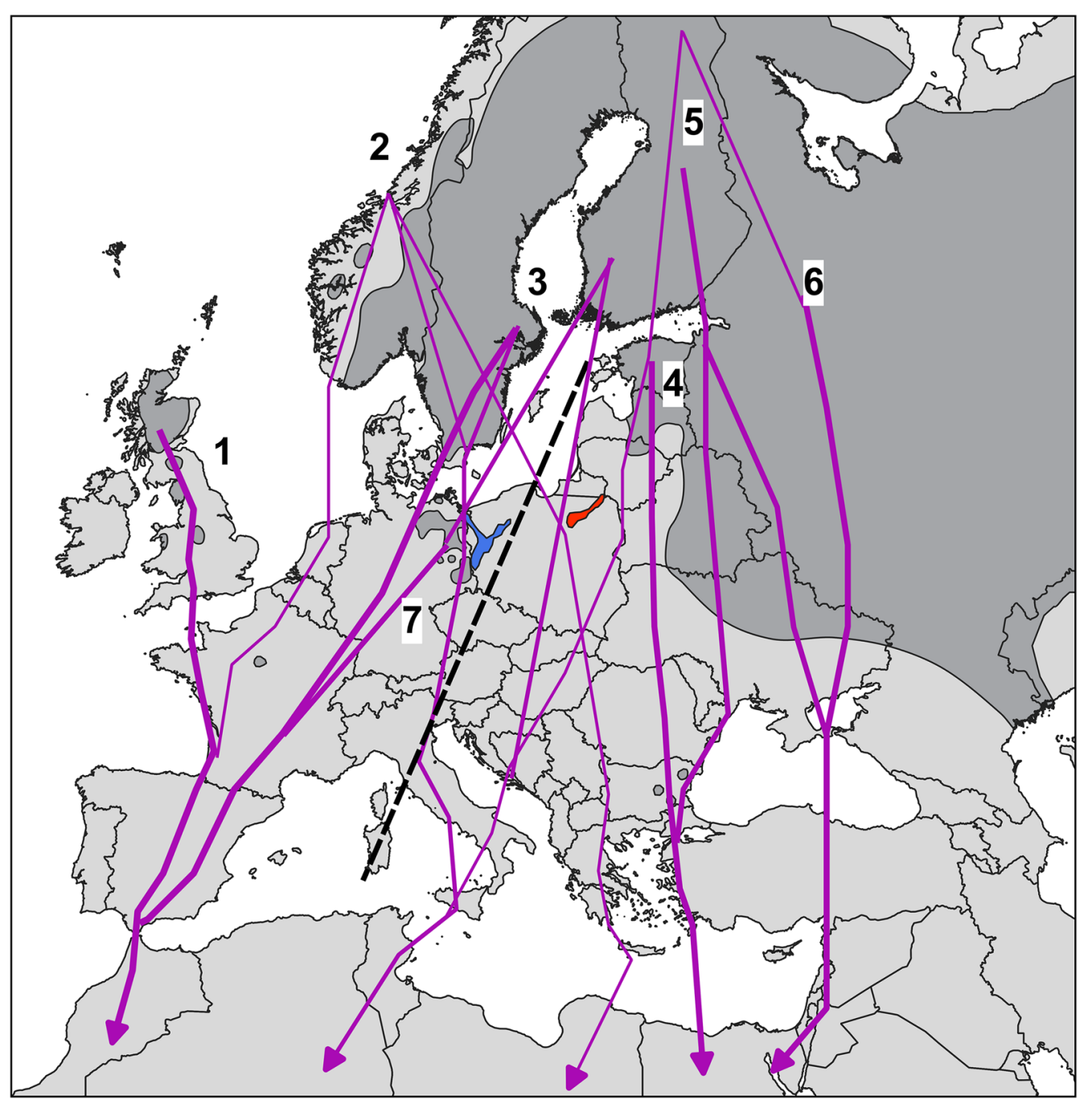

Fig. 1 Main migration paths of Ospreys from northern Europe and predicted migratory division (dashed line) between Osprey populations in eastern (red) and western (blue) Poland. Thin and thick lines show relative importance of migration paths and refer to studies by: (1) Mackrill 2017, (2) Østnes et al. 2019, (3) Alerstam et al. 2006, Klaassen et al. 2011, (4) Väli and Sellis 2015, (5) LUOMUS 2020, (6) Babushkin et al. 2019, (7) Meyburg et al. 2018 
called "clock and compass" known from passerines (Helbig 1996), we can expect that migration direction differs between populations. This assumption is supported by the philopatry phenomenon known to occur in Ospreys (Monti et al. 2018b). In this context, it might be interesting to investigate migration routes of populations in the middle of the range to check if the migration direction exhibits a continuous range or a migratory divide between the eastern and western populations of the species.

The central part of the Osprey's European range shows a break that is further prolonged by the Baltic Sea (Fig. 1). In the eastern part, species range is continuous, while in the western part, the range is fragmented but the population is increasing thanks to conservation efforts (Dennis 2016). However, between the continuous eastern and growing German population, there are small "islands" in this species' range, located in Poland. Both are in decline. Therefore, conservation actions and studies were recently carried out in order to protect this species in its last Polish populations (Anderwald 2017). We have carried out a GPS telemetry study to follow spatial ecology and mortality rates, but also to reveal if those two populations will show contrasting migratory patterns that might affect the more isolated and faster declining eastern population in particular. Taking into account the migration studies conducted so far (Fig. 1), we predict that the eastern and western populations may show a migratory divide and, therefore, might also be subjected to different selective pressure. Thus, our aim was to check whether migration paths and migration patterns differ between the eastern and western populations as well as between different age and sex classes. Also, we followed mortality rates and reasons to reveal the crucial threats for those declining populations and to check if potentially different migratory behaviour might affect it.

\section{Methods}

\section{Study area and bird tagging}

The study was carried out in two small, spatially distinct Polish populations, separated by about $235 \mathrm{~km}$ (between closest nests). The eastern population forms a small island (only 8-9 pairs in 2020) in the species range, about $200 \mathrm{~km}$ from the nearest breeding sites in Lithuania. It is located in the vast Masuria Lakeland area, where Ospreys mostly nest in the interior of large forest complexes. The western population contains about 16 pairs (in 2020) scattered in forests, but some also nesting on electric pylons on farmland. This population is slowly increasing and some exchange of individuals with Ospreys from eastern Germany was observed to occur in both directions.
Tagging was carried out in 2017-2020 and covered both chicks in nests and adults. In the first year, only a single juvenile was equipped with a 30 g "Ornitrack E30" GPS GPRS logger (manufactured by Ornitela Lithuania), while later on 4 individuals were tagged annually in 2018 and 2020 and 10 individuals in 2019, all with 35-40 g "Kite-M" GPS GPRS loggers (manufactured by Ecotone Poland). Well-developed chicks (body mass $>1420 \mathrm{~g}$ ) were caught in the nests. Adults were caught with large mist nets, provoked by a stuffed white-tailed eagle close to their nests. Devices were mounted on the birds' backs with Teflon ribbon sewn at the sternum with the "Y" method described by Buehler et al. (1995). Data were acquired with a 15-min interval, on average. Sex was identified according to body mass and biometrics (Poole 1982), although in the case of juveniles, they were treated as possible male and possible female as biometry measurements can sometimes overlap between sexes. In the case of adults, direct observations of behaviour at the nesting site and the extent of the breeding patch were found to be reliable criteria in identifying sex.

\section{Analysis}

The onset of autumn migration was determined as a long (over $30 \mathrm{~km}$ ), directional (straight-line) movement in the southern or south-western direction undertaken over at least two consecutive days. A threshold of a daily distance of $30 \mathrm{~km}$ was chosen upon a histogram of daily distance covered during the expected time of migration (August-November). Distance up to $30 \mathrm{~km}$ formed a visibly more frequent class, while distances over $30 \mathrm{~km}$ were represented with a similar frequency range (Additional file 1: Fig. S1). A stopover site was defined as an area where a bird spent more than two consecutive nights in a radius of less than $10 \mathrm{~km}$. The end of autumn migration and beginning of wintering was considered to be the last day of the long, directional movement southwards. Migration direction was measured (in QGIS) as azimuth between location at start of migration and reaching the Mediterranean Sea. At the sea-crossing point, the innate migratory direction might already be distorted by choosing the most convenient site and trying to bypass this barrier, and therefore we measured it at the early migration stage. For mortality statistics, we counted followed individual as perished, if we were able to find its dead corpse. We reported also suspicious losses of data transmission as possible mortality events, but we have not included those cases as mortality events, since tag malfunction is also a common scenario. Total and daily distance covered by the followed individuals were calculated using the moveHMM package (Michelot et al. 2016) in R 4.0.3 and two-point equidistant projection. Straight-line 
distance was calculated with the same projection in QGIS 3.16. In order to check if sex, age and population had any impact on movement speed, they were used as fixed factors in linear mixed effects models with random effect of individual built into the lme4 package (Bates et al. 2015) to explain the logarithm of daily distance covered during migration. Stopover days were excluded by limiting the dataset to days with movement over $50 \mathrm{~km}$. Models were built in additive pattern. The best supported model was chosen according to the Akaike Information Criterion (AIC). Models with $\triangle \mathrm{AIC}<2$ were averaged in the MuMIn package (Bartoń 2020). In order to check whether migration patterns differed between individuals from the two distinct populations or individuals of different sex and age, departure date, migration duration, migration direction, number of stopover days and distance covered on migration were compared in above-mentioned pairs using the Mann-Whitney test.

\section{Results \\ Migration routes}

Out of 19 Ospreys tagged with GPS tags, we recorded the autumn migration of 12:5 adults ( 1 for 2 seasons) and 7 juveniles (Table 1). The remaining 7 died before the onset of migration, juveniles mostly due to Goshawk (Accipiter gentilis) predation or fell due to unknown reasons still at the nest or in its vicinity. Two adult males died due to poaching and electrocution at the breeding grounds. Unfortunately, 3 of migrating individuals recorded incomplete tracks, but came far enough to judge their general migration paths (Fig. 2a). The Ospreys showed broad-front migration and crossed the Mediterranean Sea in a vast belt from Gibraltar to the Balkan Peninsula to winter in the central part of Western Africa (Fig. 2a). The only exception was the juvenile that wintered in the Iberian Peninsula (Table 1). Some juveniles travelled long distances over open sea, while adults tended to use less hazardous paths along the eastern shore of the Iberian Peninsula, Corsica and Italian Peninsula (Fig. 2b). Ospreys from the eastern and western populations in Poland exhibited a partial migratory divide, with most of the individuals (86\%; incl. all juveniles) from the eastern population heading south (azimuth $205.5 \pm 16.8$ ) and crossing the Mediterranean Sea at the middle to reach wintering sites in Ghana, Burkina Faso, Nigeria, Angola. On the contrary, most of the individuals (83\%) from the western population headed south-west (azimuth $221.0 \pm 20.3$ ) to cross the Mediterranean Sea at its western narrowing and winter in Senegal, Sierra Leone and Spain (Fig. 2c). Differences in azimuth were, however, not significant $(U=12, p=0.23)$. At later stages, migration direction was similar between the eastern and western population.

\section{Mortality}

We observed high mortality in juveniles in their first year, reaching $67 \%$ in the case of certain deaths, but possibly even $83 \%$ together if unknown cases of suspicious signal losses were added. Some cases even occurred before the onset of migration (Table 2). Five died at fledgling stage: one in the nest of unknown reasons, three were killed by a Goshawk and another one was killed by a wind turbine. Two juveniles died at wintering sites: one was poached in Nigeria, the other died of unknown reasons in Senegal. The last death was confirmed at the start of spring migration in Spain, probably due to Goshawk predation. Another two juveniles stopped transmitting during autumn migration: one in Italy, the other in Morocco, but we have no evidence of their death. Only two juveniles certainly survived the first year and transmitted in the next season.

Surprisingly, the mortality of adults was also high and reached 57\% (confirmed deaths) already in the first year of tracking. In this case, the reasons were highly anthropogenic in three (out of four) cases: two adults died because of electrocution (one in Senegal and one in Poland) and one was poached (still in Poland). Another individual (from the eastern population) was simply found dead (for unknown reasons) in Burkina Faso. Two other adults from eastern population stopped transmitting in the deserts and were not seen at their breeding grounds in the next year, therefore actual mortality was probably even higher.

\section{Factors affecting autumn migration}

Models explaining daily distance covered on migration were poorly distinguishable between the base model with a random effect of individual only, comparing to models involving individual's sex, age and source population (Table 3). Eventually, the averaged model involved all the factors, but all were insignificant and showed very low slope estimates (Table 4). The variance explained by the base model was low (conditional $R^{2}=0.151$ ) and barely increased when other predictors were added (conditional $R^{2}$ increased to $0.165-0.167$, depending on the model).

The departure for autumn migration did not differ significantly between individuals of different age or sex, although in the last case, surprisingly, females left breeding grounds later than males (Additional file 1: Fig. S2). Similarly, we found no effect of age or sex on migration distance, duration and number of stopover days (Fig. 3a, c, d; Additional file 1: Table S1). However, when 


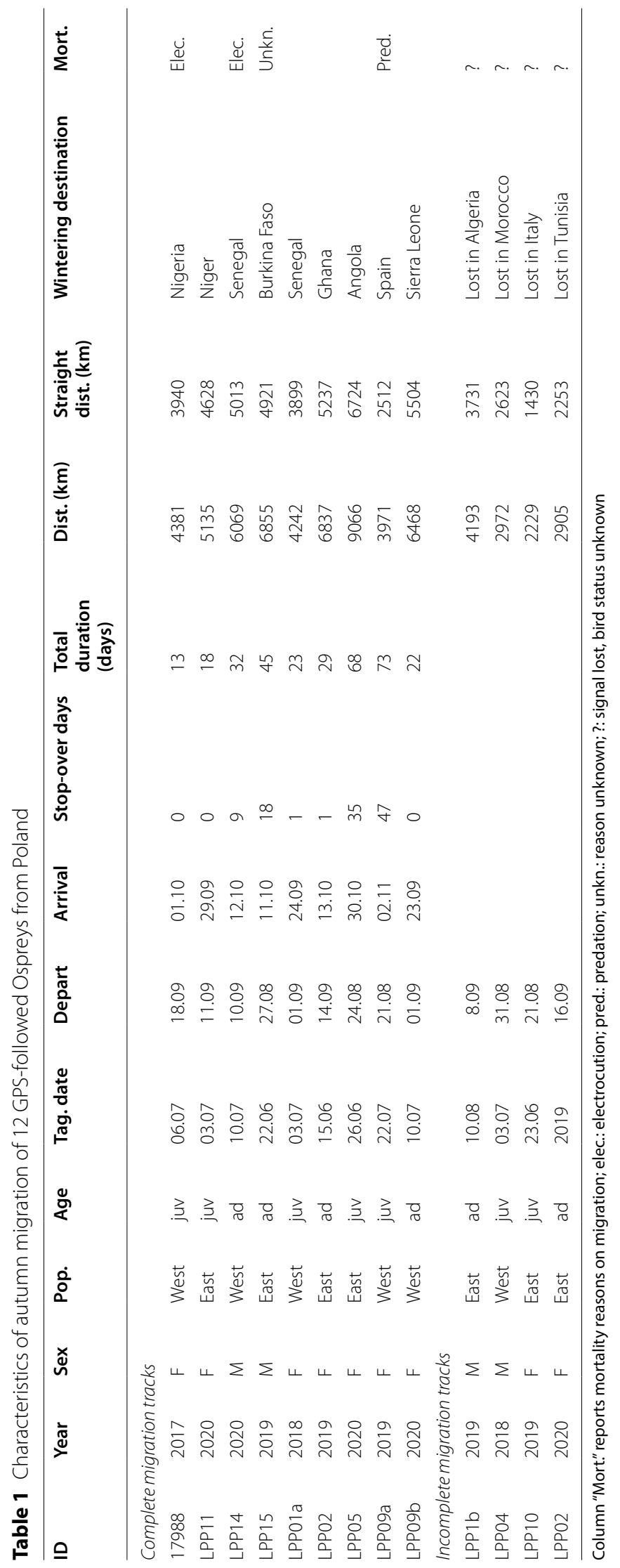



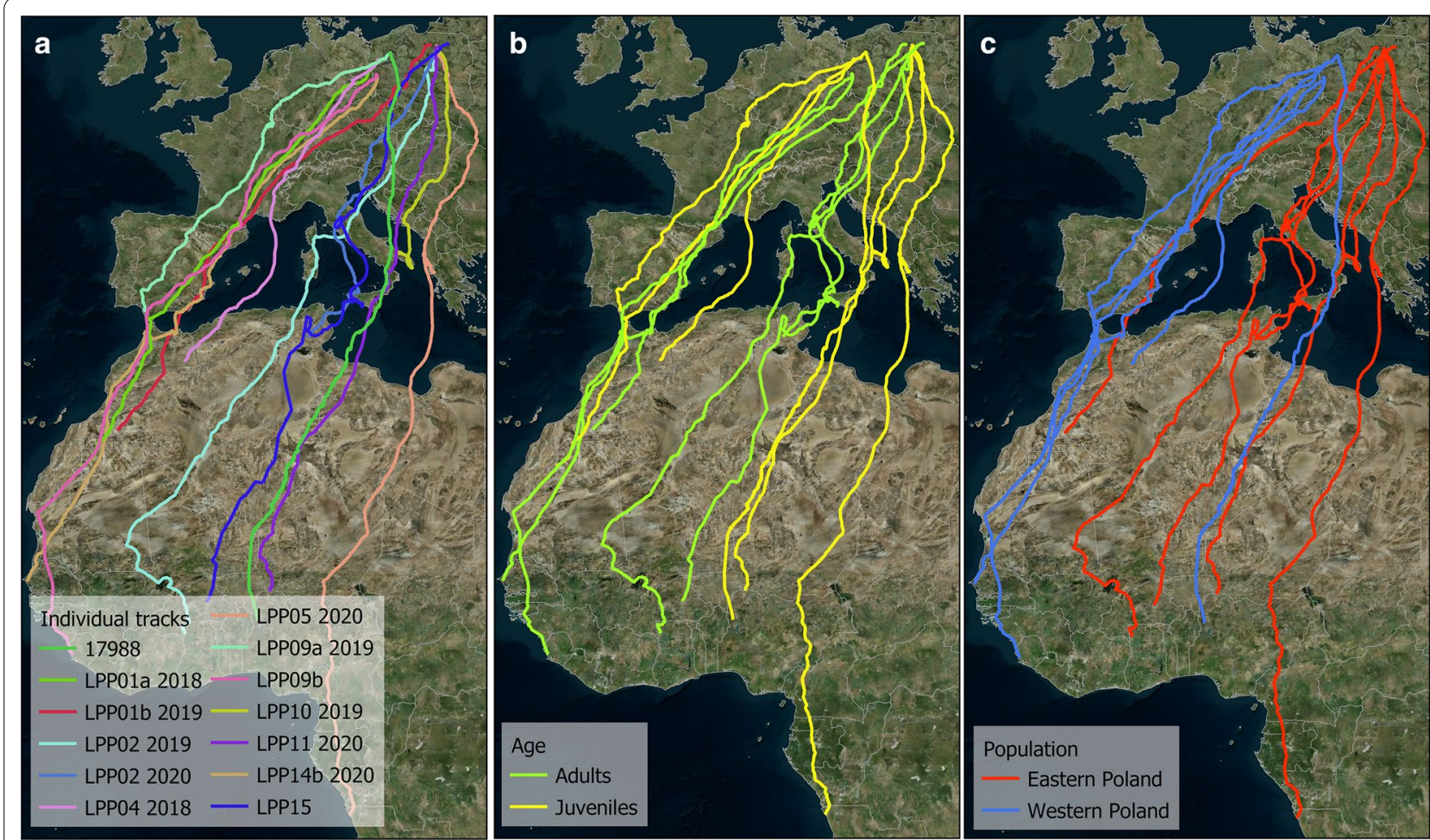

Fig. 2 Autumn migration paths of GPS-tagged Ospreys from Poland shown by individual (a), age (b) and source population (c)

Table 2 Mortality numbers of 19 GPS-tagged Ospreys from Poland in 2017-2020

\begin{tabular}{lll}
\hline Season & \multicolumn{2}{l}{ Number of deaths } \\
\cline { 2 - 3 } & Juveniles & Adults \\
\hline Breeding & 5 & 2 \\
Wintering & 2 & 2 \\
Autumn migration & 0 & 0 \\
Spring migration & 1 & 0
\end{tabular}

individuals from different source populations were compared, the distance covered on migration was almost significantly higher in the eastern than in the western population (Fig. 3b) although straight-line distance was almost the same $(U=15, p=0.286)$. When migration was divided into sections, juveniles covered some surplus kilometres across land in Europe, compared to adults (Fig. 4a). Individuals from the eastern population covered shorter distances over land in Europe, but longer over

Table 3 Components of linear mixed effects models of daily distance covered by GPS-tagged Ospreys from Poland on autumn migration in 2018-2020

\begin{tabular}{lllllll}
\hline No & Model components & df & logLik & AIC & UAIC & Weight \\
\hline 1 & Random effect of individual (1||D) & 3 & -261.78 & 529.54 & 0 & 0.62 \\
2 & Age+(1||D) & 4 & -261.71 & 531.42 & 1.88 & 0.13 \\
3 & Sex+(1||D) & 4 & -261.76 & 531.52 & 1.98 & 0.13 \\
4 & Population+(1||D) & 4 & -261.76 & 531.53 & 1.99 & 0.12 \\
5 & Age+Sex+Population + (1||D) & 6 & -261.74 & 535.28 & 5.74 & - \\
\hline
\end{tabular}

Akaike Information Criterion (AIC) showed models No. 1-4 were barely distinguishable, therefore were averaged and their contribution to the best supported model is given in the "weight" field 
Table 4 The best supported model of daily distance (logarithm) covered by GPS-tagged Ospreys from Poland on their autumn migration in 2018-2020

\begin{tabular}{llrr}
\hline Predictors & \multicolumn{2}{l}{ Log (daily distance) } \\
\cline { 2 - 4 } & Estimates & \multicolumn{1}{l}{ Cl } & \multicolumn{1}{c}{$\boldsymbol{p}$} \\
\hline (Intercept) & 5.24 & $4.99-5.48$ & $<0.001$ \\
Sex (male) & -0.03 & $-0.50-0.43$ & 0.884 \\
Population (west) & 0.03 & $-0.42-0.48$ & 0.904 \\
Age (juvenile) & -0.06 & $-0.50-0.37$ & 0.773 \\
$N_{\text {ID }}$ & 13 & & \\
Observations & 232 & & \\
\hline
\end{tabular}

Intercept includes adult females from the eastern population

sea and the Sahara Desert (Fig. 4b). Unfortunately, the sample size was too small to perform reliable statistical comparisons.

In general, the dynamics of migration was rather even in adults, but showed longer stopovers and more pronounced stopover behaviour in some juveniles (Additional file 1: Fig. S3). Individuals of both age groups were capable of covering a distance of around $800 \mathrm{~km}$ in $24 \mathrm{~h}$.

\section{Discussion}

Overall, the Ospreys from the two distinct populations differed in their migration routes. With single exceptions, individuals from the eastern and western populations headed south and south-west, respectively. Eastern juveniles, which are supposed to follow their innate migratory mechanism at first migration (Väli et al. 2018), tended to cross the Mediterranean Sea further east than adults, highlighting the difference in direction between eastern and western population. Taking into account that migratory direction is inherited, single exceptions from the main flyways may show that the two populations are not entirely isolated. Osprey males are highly philopatric and breed in the radius of about $30 \mathrm{~km}$ from their natal sites (Kinkead 1985). On the contrary, females can show quite long dispersal and may breed hundreds of kilometres from their birth site. In the mentioned population of the Osprey in eastern Poland, alien females (but not males), ringed in Germany and Latvia $(>500 \mathrm{~km})$, were recorded to breed. Thus, gene flow with
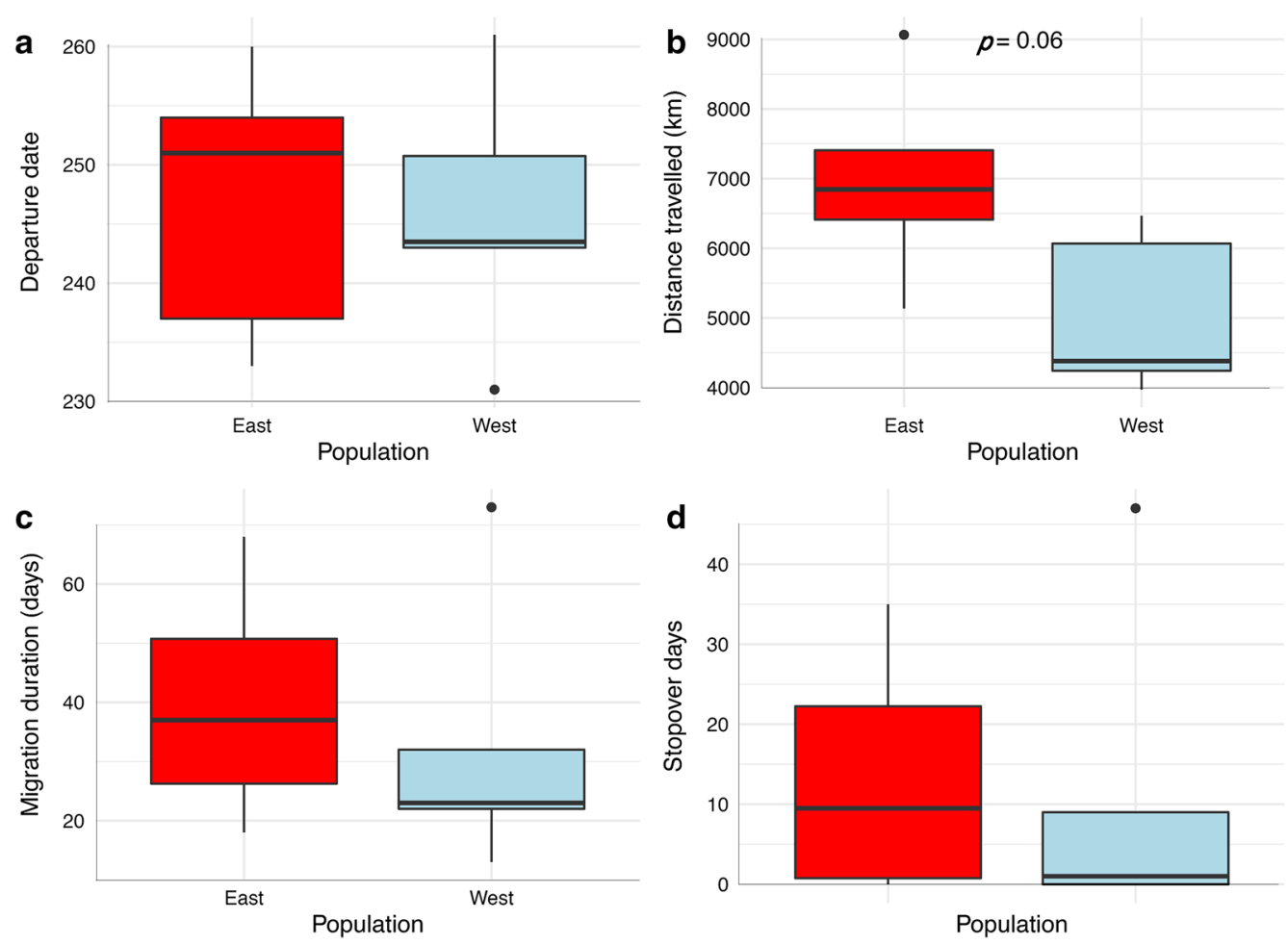

Fig. 3 Departure date (a), total distance $(\mathbf{b})$, duration of migration (c) and number of stopover days (d) shown by GPS-tagged Ospreys from eastern (red) and western (blue) Poland on their autumn migration. $p$ value of the Mann-Whitney test between populations is given for close-to-significant differences 


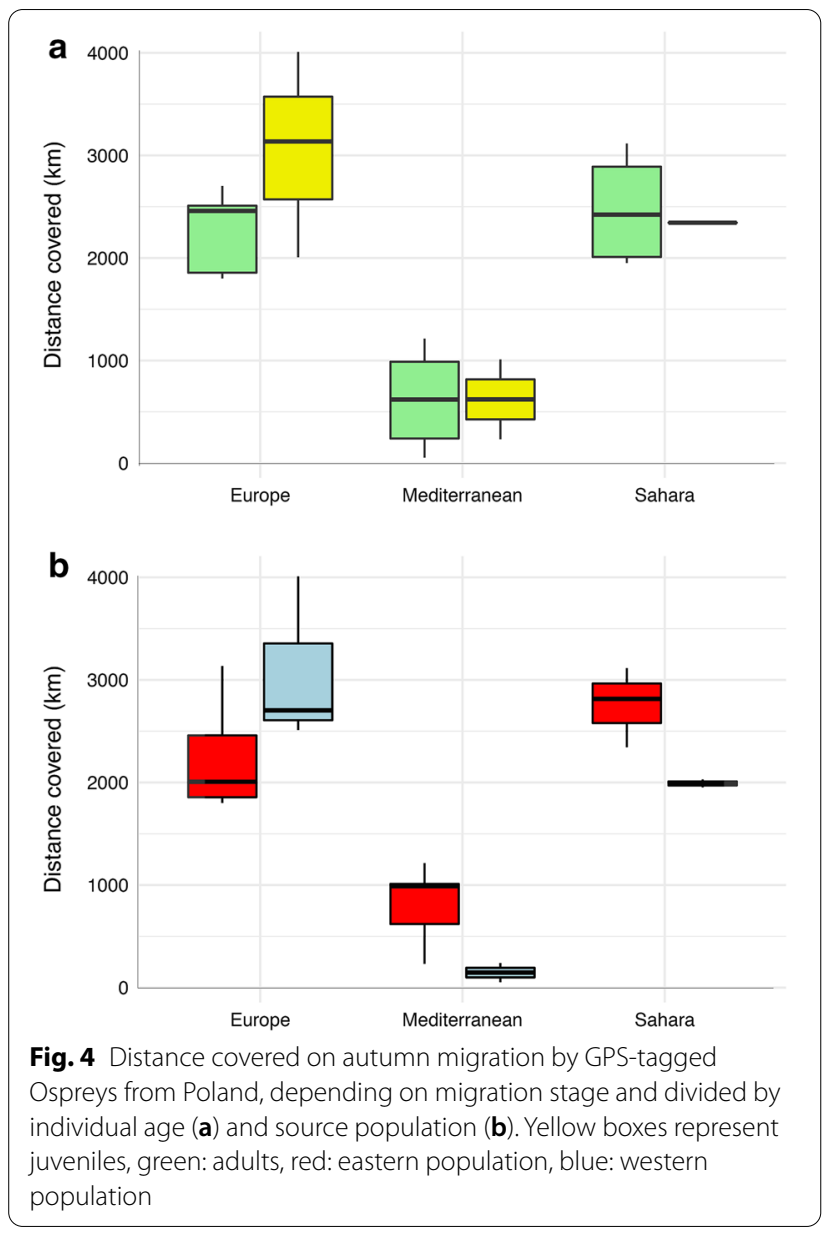

populations of different migration paths certainly occurs, although with low frequency, as shown for other European populations by Monti et al. (2018b). The authors of the above-mentioned paper reveal that gene flow and migratory behaviour are linked in Europe and the central location of Polish populations might attract dispersing females from three different migratory pathways. However, looking at the rather distinct migratory pathways of Ospreys belonging to the western and central populations studied, gene flow rates are rather low. Preliminary genetic analysis done on Polish Ospreys showed relatively high heterozygosity in the small sample set dominated by the western population. All individuals from this population represented one haplotype (Rutkowski 2019), common for Ospreys in northern and western Europe (Monti et al. 2018b). On the other hand, unique alleles were found in a single individual examined from the eastern population (Rutkowski 2019). This fact may indicate relatively high genetic distance between the two mentioned populations, but needs further confirmation in a greater sample size.
Migration patterns, at least for tested traits, did not differ between age and sex classes. This was quite surprising, since many studies have shown females depart much earlier than males (Bai and Schmidt 2012; Väli and Sellis 2015; Meyburg et al. 2018), adult females and juveniles cover longer distances than adult males (Bai and Schmidt 2012), and males use fewer days for stopovers than females (Alerstam et al. 2006; Meyburg et al. 2018). In terms of the departure date, the difference should be sharp, but not only was this not observed in adult females, but we found them departing later than adult males. This might be an artefact caused by the low sample size, but also it may indicate that foraging conditions were optimal and inter-species competition is low in those small populations. Therefore, instead of moving to other foraging sites, the breeding grounds were suitable for "filling their tanks" before migration. In contrary to other mentioned studies, we did not find age or sex to affect migration dynamics, but also showed that it is variable, especially in the case of juveniles (Additional file 1 : Fig. S3).

Individuals from different source populations, although located along similar latitudes, exhibited close-to-significant differences in migration distance (Fig. 3b), with individuals from the eastern population covering, on average, over $2000 \mathrm{~km}$ more to reach wintering sites. When migration was divided into stages, we found that the main difference in migration length lies in the most risky parts: crossing the Mediterranean Sea and Sahara Desert (Fig. 4b). This fact may be a factor in differing survival rates and the opposite population trend patterns in the two populations across the migratory divide. Such a pattern was shown for the Common Cuckoo (Cuculus canorus) in Great Britain, which uses two different paths on its way to wintering sites in Africa (Hewson et al. 2016). Those that followed the central Mediterranean passage and later headed through the central part of the Sahara Desert exhibited higher mortality and, in consequence, declined.

We found mortality rates in Polish Ospreys to be high in juveniles, which was expected, but also high in adults. It seems odd that mature and experienced Ospreys in our study do not demonstrate a significant increase in survival. However, other studies support the expected increase in survival with age (i.e. Wahl and Barbraud 2014; Väli et al. 2021). Monti et al. (2014) showed survival of translocated juveniles reaching only $26 \%$ in their first autumn/winter season, while in the second calendar year it reached 69\%, and later increased in adults to $93 \%$. In France, the survival of individuals reached $49 \%$ in their first year and as much as $87 \%$ in the second year and in older birds (Wahl and 
Barbraud 2014). Even higher rates were noted in Swedish Ospreys; $65 \%$ of year-old birds survived the first year and 81\% thereafter (Ryttman 1994). In Latvia and Estonia, survival of 1-year old birds was reached only $14 \%$ for young females and $27 \%$ for young males, while in older individuals it reached $64 \%$ and $74 \%$, respectively (Väli et al. 2021). In North America, survival in the first year was estimated to be as much as $47 \%$, while in adults to ca. 81\% (Henny and Wight 1969). All of these data reported above were based on ringing recoveries and were much higher than the ones reported in our telemetry study. Certainly, GPS devices are more precise in showing where and when mortality exactly occurred and probably less biased than survival estimates from capture-recapture methods. At the same time GPS tags themselves were not found to affect survival of followed individuals (Väli et al. 2021).

In the case of adults, a huge part of mortality was attributed to anthropogenic reasons. We have noted surprisingly small mortality on migration, contrary to what is expected, given the results of Klaassen et al. (2014) on a few migratory birds of prey species, including the Osprey. However, probably also in our case, the mortality on migration is higher and at least some individuals that stopped transmitting on migration, actually perished. Birds' corpses were not found in those cases, which is not surprising especially in the deserts. However, considering the early death of unknown reason of individual just reaching the wintering grounds and two individuals missing while flying through deserts, eastern population seems more susceptible to losses on migration. This corresponds to greater distance they covered, especially at the most hazardous points on the migration route (sea and desert; Fig. 4b). Greater distance covered during migration is associated with a higher risk of mortality in Ospreys, but also in other migratory birds of prey (de Pascalis et al. 2020). The mortality reasons are not necessarily directly linked to longer and more hazardous paths, but may impact the birds' condition by weakening them and making them more susceptible to predation, poaching and starvation, i.e. "disappearing" in the deserts or dying of unknown causes. Certainly, the high mortality of Ospreys from declining Polish population requires further investigation to reveal the most important threats and subsequently counteract them.

\section{Conclusions}

Two small and distinct Osprey populations showed a clear but incomplete migratory divide, despite being separated by only a few hundred kilometres, a distance that did not completely limit gene flow through female dispersal. We found high mortality rates in juvenile and adult
Ospreys, which were relatively higher while on migration in the case of the eastern population. There may be a link between migration route and mortality rates that led to the steeper decline of the eastern population; however, the sample size of tagged individuals is too low at the moment to make any definite conclusions.

\section{Supplementary Information}

The online version contains supplementary material available at https://doi. org/10.1186/s40657-021-00281-6.

Additional file 1: Figure S1. Histogram of daily distance covered on migration by GPS-tracked Ospreys from Poland in 2017-2020. Figure S2. Differences in departure dates between age and sex classes in GPStracked Ospreys from Poland on their autumn migration. Figure S3. Distance covered daily on migration by juvenile (a) and adult (b) Ospreys from Poland followed with GPS loggers in 2017-2020. Table S1. Results of Mann-Whitney test comparing autumn migration traits between individuals of different sex, age and source population (eastern vs. western) among nine Ospreys from Poland followed with GPS telemetry in 2017-2020.

\section{Acknowledgements}

We would like to thank Michał Dzwonkowski, Dariusz Kujawa, Cezary Korkosz, Tomasz Kryjan, Stefan Lewandowski, Marcin Sołowiej, Piotr Waszczykowski and Paweł Czechowski for their help in the fieldworks conducted.

\section{Authors' contributions}

DA designed the study and obtained funding. PM led data analysis and manuscript writing. DA, MZ, ŁC, SR participated in data analysis and writing. All co-authors were involved in the fieldwork. All authors read and approved the final manuscript.

\section{Funding}

The study was carried out over the course of the project "Osprey conservation in selected SPA Natura 2000 sites in Poland", LIFE15 NAT/PL/000819 funded by the European Union under the LIFE + programme and the National Fund for Environmental Protection and Water Management in Poland.

\section{Availability of data and materials}

The dataset supporting the conclusions of this article is stored in the Movebank repository, ID 365184781 and available on request.

\section{Declarations}

Ethics approval and consent to participate

Catching and tagging of Ospreys were carried out under the license of General Inspectorate for Environmental Protection_DZP.WG.6401.03.109.2017.dł.

\section{Consent for publication}

Not applicable.

\section{Competing interests}

The authors declare that they have no competing interests.

\section{Author details}

${ }^{1}$ Forest Experimental Station in Rogów, Akademicka 20, 95-063 Rogów Poland. ${ }^{2}$ Eagle Conservation Committee, Niepodległości 53/55, 10-044 Olsztyn, Poland. ${ }^{3}$ Faculty of Biology, University of Białystok, Ciołkowskiego $1 \mathrm{~J}$, 15-245 Białystok, Poland.

Received: 31 December 2020 Accepted: 6 September 2021

Published online: 15 September 2021 


\section{References}

Alerstam T, Hake M, Kjellén N. Temporal and spatial patterns of repeated migratory journeys by ospreys. Anim Behav. 2006;71:555-66.

Anderwald D. The Osprey Pandion haliaetus in Poland-situation of the species (in Polish). Studia Mat CEPL. 2017;19:8-30.

Babushkin M, Kuznetsov A, del Mar DM. Autumn migratory patterns of northwest Russian Ospreys Pandion haliaetus. Ardeola. 2019;66:119-28.

Bai ML, Schmidt D. Differential migration by age and sex in central European Ospreys Pandion haliaetus. J Ornithol. 2012;153:75-84.

Bartoń K. MuMIn: Multi-model inference. R package ver. 1.43.17. 2020. https:// cran.r-project.org/web/packages/MuMln/index.html.

Bates D, Mächler M, Bolker B, Walker S. Fitting linear mixed-effects models using Ime4. J Stat Soft. 2015;67:1-48.

Bierregaard RO, Poole AF, Washburn BE. Ospreys (Pandion haliaetus) in the $21 \mathrm{st}$ century: populations, migration, management, and research priorities. J Raptor Res. 2014;48:301-8.

Buehler DA, Fraser JD, Fuller MR, McAllister LS, Seegar JKD. Captive and fieldtested radio transmitter attachments for bald eagles. J Field Ornithol. 1995;66:173-80.

Dennis R. Plan for the recovery and conservation of Ospreys in Europe and the Mediterranean region in particular. In: Convention on the conservation of European wildlife and natural habitats. Standing Committee, 36th meeting, Strasbourg. 2016

de Pascalis F, Panuccio M, Bacaro G, Monti F. Shift in proximate causes of mortality for six large migratory raptors over a century. Biol Conserv. 2020;251:108793.

Helbig A. Genetic basis, mode of inheritance and evolutionary changes of migratory directions in palaearctic warblers (Aves: Sylviidae). J Exp Biol. 1996;199:49-55.

Henny CJ, Wight HM. An endangered Osprey population: estimates of mortality and production. Auk. 1969;86:188-98.

Hewson CM, Thorup K, Pearce-Higgins JW, Atkinson PW. Population decline is linked to migration route in the Common Cuckoo. Nat Commun. 2016;7:12296.

Kinkead TP. Age structure and dispersal of Chesapeake bay Ospreys. Master's Thesis. Virginia: College of William and Mary; 1985.

Klaassen RHG, Hake M, Strandberg R, Alerstam T. Geographical and temporal flexibility in the response to crosswinds by migrating raptors. Proc $\mathrm{R} S \mathrm{Soc}$ B. 2011;278:1339-46.

Klaassen RHG, Hake M, Strandberg R, Koks BJ, Trierweiler C, Exo K-M, et al. When and where does mortality occur in migratory birds? Direct evidence from long-term satellite tracking of raptors. J Anim Ecol. 2014;83:176-84.
LUOMUS. Finnish satellite Ospreys. 2020. https://www.luomus.fi/en/finnishsatellite-ospreys. Accessed 20 Dec 2020.

Mackrill TR. Migratory behaviour and ecology of a trans-Saharan migrant raptor, the Osprey Pandion haliaetus. Doctoral Thesis. Leicester: University of Leicester; 2017.

Martell MS, Henny CJ, Nye PE, Solensky MJ. Fall migration routes, timing, and wintering sites of North American Ospreys as determined by satellite telemetry. Condor. 2011;103:715-24.

Meyburg B-U, Roepke D, Meyburg C, van Wijk RE. Sex-specific migration strategies of ospreys (Pandion haliaetus) from Germany. bioRxiv. 2018. https:// doi.org/10.1101/398735.

Michelot T, Langrock R, Patterson TA. moveHMM: an R package for the statistical modelling of animal movement data using hidden Markov models. Method Ecol Evol. 2016;7:1308-15.

Monti F, Dominici JM, Choquet R, Duriez O, Sammuri G, Sforzi A. The Osprey reintroduction in Central Italy: dispersal, survival and first breeding data. Bird Study. 2014;61:465-73.

Monti F, Grémillet D, Sforzi A, Sammuri G, Dominici JM, Triay R, et al. Migration and wintering strategies in vulnerable Mediterranean Osprey populations. Ibis. 2018a;160:554-67.

Monti F, Delfour F, Arnal V, Zenboudji S, Duriez O, Montgelard C. Genetic connectivity among osprey populations and consequences for conservation: philopatry versus dispersal as key factors. Conserv Genetics. 2018b;19:839-51.

Østnes JE, Kroglund RT, Kleven O, Nygård T. Migratory patterns of Ospreys (Pandion haliaetus) from central Norway. Ornis Fennica. 2019;96:101-11.

Poole A. Brood reduction in temperate and subtropical Ospreys. Oecologia. 1982;53:111-9.

Rutkowski R. Report on genetic analyses carried out on Ospreys from Poland. Warsaw: Museum and Institute of Zoology; 2019.

Ryttman $\mathrm{H}$. Estimates of survival and population development of the Osprey Pandion haliaetus, Common Buzzard Buteo buteo, and Sparrowhawk Accipiter nisus in Sweden. Ornis Svec. 1994;4:159-72.

Väli Ü, Sellis U. Migration patterns of the Osprey Pandion haliaetus on the Eastern European-East African flyway. Ostrich. 2015;87:23-8.

Väli Ü, Mirski P, Sellis U, Dagys M, Maciorowski G. Genetic determination of migration strategies in large soaring birds: evidence from hybrid eagles. $P$ Roy Soc Lond B Biol. 2018;285:20180855.

Väli Ü, Kalvāns A, Tuvi J. Apparent survival and dispersal in a recovered Osprey population: effects of age, sex and social status. J Ornithol. 2021. https:// doi.org/10.1007/s10336-021-01908-7.

Wahl R, Barbraud C. The demography of a newly established Osprey Pandion haliaetus population in France. Ibis. 2014;156:84-96.
Ready to submit your research? Choose BMC and benefit from:

- fast, convenient online submission

- thorough peer review by experienced researchers in your field

- rapid publication on acceptance

- support for research data, including large and complex data types

- gold Open Access which fosters wider collaboration and increased citations

- maximum visibility for your research: over 100M website views per year

At BMC, research is always in progress.

Learn more biomedcentral.com/submissions 